$1-1-1893$

\title{
Experiments on potatoes, at the station ; Experiments on corn, at the out-stations
}

D. D. Johnson

Follow this and additional works at: https://researchrepository.wvu.edu/ wv_agricultural_and_forestry_experiment_station_bulletins

\section{Digital Commons Citation}

Johnson, D. D., "Experiments on potatoes, at the station ; Experiments on corn, at the out-stations" (1893). West Virginia Agricultural and Forestry Experiment Station Bulletins. 29.

https://researchrepository.wvu.edu/wv_agricultural_and_forestry_experiment_station_bulletins/29 

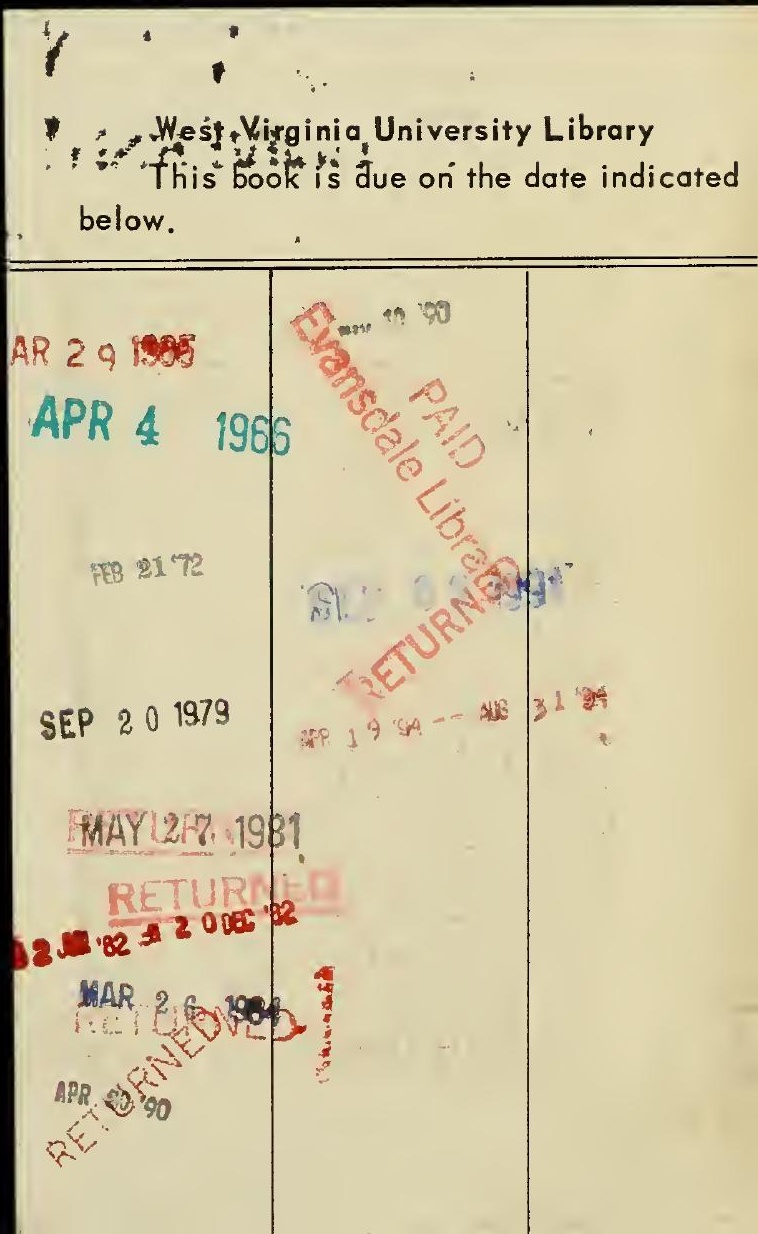



\section{Bulletin No. 29}

\section{WEST VIRGINIA 。}

\section{Agriculturàl Éxperiment Station}

MURGANTOWN, W. VA.

1. Experiments on Potatoes, at the Station.

2. Experiments on Corn. at the Out-Stations

AGRICULTURAL. DEPARTMENT

$$
\text { January } 184 \%^{\circ}
$$

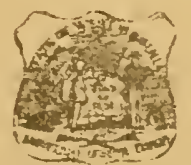




\section{BOARD OF REGENTS OF THE WEST VIRGINIA UNIVERSITY,}

\begin{tabular}{|c|c|c|}
\hline Disartet & Nyme of Regenl. & F. O. Adaress. \\
\hline $\mathbf{r}$. & J. B. SOMMERVILLE, & Wheeling. \\
\hline 2. & CLARENCE L. SMITH, & Fairmont. \\
\hline 3. & R. G. LYNN, & Glenville. \\
\hline 4 . & JOHN C. VANCE, & Clarksburg. \\
\hline & JOHN G. SCHILLING, & Spencer. \\
\hline o. & EDWARD A. BENNETT, & Huntington. \\
\hline 7. & WIRT A. FRENCH, & Princeton. \\
\hline ૪. & M. J. KESTER, & Union. \\
\hline 9. & J. F. BROWN, & Charleston. \\
\hline 0 & THOS. J. FARNSW & Buckhannon: \\
\hline & $\begin{array}{l}\text { JOSEPH MORELAND } \\
\text { JOHN A. ROBINSON, }\end{array}$ & $\begin{array}{l}\text { Morgantown. } \\
\text { Patterson's Depot. }\end{array}$ \\
\hline & DR & Kabletown. \\
\hline
\end{tabular}

\section{MEMBERS OF THE STATION COMMITTEE,}

JOHN A. ROBINSON,
JOSEPH MORELAND, DR. W. W. BROWN.

Prest, of Board of Regents,

PRESIDENT OF THE UNIVERSITY,

E. M. TURNER, LL. D.,
JOHN A MYERS, YH. D.,

F. WN. RANE, M. S.

A. D. HOPKINS,

D. D. JOHNSON, A. M.,

RUDOLF DE ROODE, PH. D.,

SUSIF V. MAYERS.
JOHN I. HARVEY.

C. L. SMITH,

J. B. SOMMERVILLE,

JOHN A. RUBINSON.

TREASURRR, 


\section{POTATO CULTURE AND FERTILIZATION.}

By D. D. JOHnson, Agriculturist.

In 189 i we conducted an experiment $3 t$ the Station for the purpose of determining the effects of Kainit used alone, and conlbined with phosphoric acid and nitrogen, as a fertilizer in growing potatoes, and in connection therewich, to test the production of some leading varieties, and the comparative effects which would be produced by planting the whole potato, the halves, the quarters, and cut in pieces each having one eye. The results of thar experiment were published in Bulletin No. 20, of January, 1892. The following is a repetition of the experiment made in $\mathrm{i} 89 \mathrm{I}$, each plat occupying the same ground that it did then, except that the rows were placed a littie closer together to avoid the "old stony ferce row, "which, to a slight extent, interfered with the accuracy of the former experiment.

It is stated in Bulletin No. 20 that the land upon which the experiment was made "is a yellowish gray soil, and has probably been cultivated for more than fifty years, being so completely 'worn out' that there was no profit, but an actual loss in its cultivation." The crop this year was almost a complete failure, caused by the unfavorable season, and the exhausted condition of the soil. The latter of these causes will be more particularly referred to when we come tu speak of the productions of Plat Ir.

The first twelve rows of each plat were planted with Early Rose; the second twelve with White Star, and the third twelve with Beauty of Hebron. The first three rows of each variety were planted with whole potatoes, one in each hill, the hills three feet apart, making six hills in each row on each plat. The second three rows of each variety were planted with halves cut lengthwise, one piece in each hill, the hills eighteen inches apart. The third three rows were planted with quarters cut lengthwise, one piece in each hill, the hills nine inches apart; and the fourth three rows of each variety were planted with pieces containing one eye each, ihree pieces in each hill, the hills nine inches apart, the object being to secure the same amcunt of "seed" in each row.

The Early Rose and White Star were planted on the 8th, and the Beauty of Hebron on the izth of April. The potatoes were fertilized when the more vigorous plants were three inches high. The plants produced by the whole potato canse up with the usual 
vigor and thrift, but those from the halves quarters and single eyes were diminutive, "spindling" and weakly, showing a very marked contrast between them and the plants from the whole potatoes. It is a well known fact that the young plant at first draws its entire nourishment from the seed which produces it. The source of supply is only temporary; therefore, the plant puts forth roots to draw its nourishment from the soil as the original source of supply becomes exhausted. While in this transition state, unless the soil be well supplied with available plant food, the plant becomes weak, "spindling," starved, and fails to make the necessary growth. In the experiment in $189 \mathrm{r}$, there was only a very slight difference in the growth of the plants produced by the whole potato, from those produced by the halves, qu rters and single eyes. We must, thertfore, conclude that the difference in the early growth of the plants in the experiment of 1892 was caused by the almost complete exhaustion of the natural available plant food in this soil by the crop of $189 \%$. The plant food contained in the seed furnished the plants produced by the whole potato, a sufficient amount of nourishment to enable the plant to change its source of supply from the "seed" potatoes to the soil with less serious results, while the others were compelled to make this change and adapt themselves to the new condition with one-half and one-fourth this support. The growth of all these plants, after the nourishment contained in the "seed" potato had become exhausted and the change to plant the food contained in the soil had been accomplished, was comparatively the same. About the ffrst of June, the plants produced by the whole potato were about three times as large as the others, while on the $1^{\text {th }}$ of July, they were about one-ffth cr twenty per cent. larger. It seems from this experiment, when compared with that of $189 \mathrm{I}$, that it is much more disastrous to the productive powers of the plant to deprive it of the necessary plant-food while it is young, than to do so when it is making its fruit, especially is this the case in the Early Rose variety.

Following the lines of investigation laid down in Bulletin No. 20, the results of this experiment will be treated as follows:

Ist. The comparative yield of large and small tubers of the several varieties produced by the use of different fertilizers.

2nd. The increased yield produced by different fertilizers; their cost, and profit and loss.

3rd. The comparative yield of tubers, planted whole, in halves, quarters, and cut to single eyes. 
TABLEA。

Showing the liesults of the wse of Commercial fiertilizers in growing Potaloes.

\begin{tabular}{|c|c|c|c|c|c|c|c|c|c|c|c|c|c|c|c|c|}
\hline & \multirow{3}{*}{ 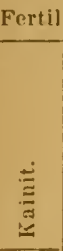 } & \multirow{3}{*}{ 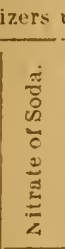 } & \multirow{3}{*}{ 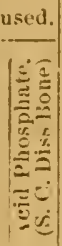 } & \multicolumn{4}{|c|}{ Jarly Rose. } & \multicolumn{3}{|c|}{ White Star. } & \multicolumn{3}{|c|}{ Heatuty of Irebron. } & \multicolumn{3}{|c|}{ Total. } \\
\hline & & & & : & & 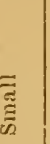 & इ & 通 & 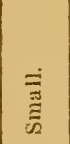 & & 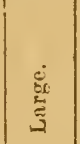 & 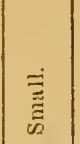 & ${ }_{\overrightarrow{0}}^{\bar{J}}$ & 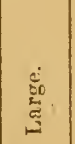 & 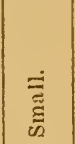 & 를 \\
\hline & & & & Lb: & & bs. & Lbs. & Lbs. & Lbs. & Lbs. & Lbs. & Lbs. & Lbs. & I.U. & Lbs. & Lbs. \\
\hline 1 & 42 & & & 38 & & 10. 1 & 48.7 & t5. .9 & 12.2 & 58.1 & 21.0 & 12.6 & 33.6 & 105.4 & 34.9 & 140.4 \\
\hline & 42 & 8.33 & & 26 & & 11.0 & 37.5 & 40.8 & 12.6 & 53.4 & 19.4 & 6. 8 & 25.2 & 86.7 & 30.4 & $11 \pi .1$ \\
\hline$?$ & 42 & & 21 & 34 & & 11.2 & 45.5 & 59.8 & 12.2 & $7 \approx 0$ & 32.3 & 10.6 & 42.9 & 126.4 & 34.0 & 160.2 \\
\hline & 42 & $8.3:$ & 3) 21 & 19 & & $\pi .5$ & $2 \pi .0$ & 45.8 & 13.0 & 58.8 & 24.1 & 8.5 & 32.6 & 89.4 & 29.0 & 118.4 \\
\hline & Noth & ing. & & 16 & & 11.0 & 27.5 & 23.9 & 15.1 & 39.0 & 12.6 & 9.4 & 200 & 53.0 & 35.5 & 88.5 \\
\hline & $31 \frac{1}{2}$ & & & 18 & & $\pi .4$ & 256 & 24.7 & 11.2 & 35.9 & 14.9 & 9.9 & 24.8 & 57.8 & 28.5 & 86.3 \\
\hline & $311 / 2$ & 8.38 & & 20 & & 9.7 & 30.0 & 18.6 & 12.0 & 30.6 & 9.8 & 6.9 & 16.7 & 48.7 & 98.6 & 77.3 \\
\hline & $311 / 2$ & & 2 & & & 17.7 & 44.0 & 39.4 & 12.2 & 51.6 & 29.4 & 11.0 & 40.4 & 95.1 & 40.9 & 136.0 \\
\hline & 31 t2 & 8.33 & 2 & & & 15.0 & 40.3 & 43.0 & 13.1 & $56: 1$ & 30.4 & 12.6 & 43.0 & 98.7 & 40.7 & 139.4 \\
\hline & 21 & & & & & 11.9 & 24.1 & 12.9 & 9.5 & 22.4 & 17.1 & 12.0 & 29.1 & 42.2 & 33.4 & 75.6 \\
\hline 11 & Nolh & ling. & & & & 12.7 & 35.3 & 21.6 & 13.8 & 38.4 & 25.1 & 16.0 & 41.1 & 73.3 & 32.5 & 114.8 \\
\hline
\end{tabular}


x. The comparative yield of large and small tubers of the several varieties, etc.

Table A sets forth in detail the amount and kind of fertilizers used on each plat, and the yield of large and small tubers of edch variety. The very largely increased percentage of small potatoes in the crop of 1892 over that of $189 \mathrm{~T}$ was caused, no doubt, by the exhausted condition of the soil and the unfavorable season. The plants made the effort to produce a crop, but failed Decause of the lack of sufficient nourishment to develop the tubers to their normal size. Taking the first four plats, a combination of Kainit and S C. Dissolved Bone produced the greatest amount of large and the smallest percentage of small tubers. Kaintt alone stands next. A combination of Kainit, S. C. Dissolved Bone and Nitrate of Soda takes third place, while a combination of Kainit and Nitrate of Soda produces the smallest amount of large and the greatest percentage of small tubers. In the second four plats, from six to nine inclusive, where the amount of Kainit is reduced one-fourth, a combination of all thres fertilizers produces the greatest amount of large and the smallest percentage of small tubers. A combination of Kainit and S. C. Dissolved Bone (Potash and Phosphoric Acid) stands next, and Kainit takes the third place, while Kainit and Nitrate of Soda again produces the smallest amount of large and the greatest percentage of small tubers In the experiment of $18 \mathrm{gr}$, the same conditions exist throughout with the single exceptions that in the first four plats, the Kainit plat and the Kainit and Nitrate of Soda plat exchange places. We are utterly unable to accsunt for the comparatively large yield of Plat $\mathrm{I}$, in the crop of 1892 , but this yield accounts for the difference in the results of the experiments for the two years, as just stated.

From this part of the experiment, we draw the same inference we did last year, viz: "The more efficient the fertilizer, the less will be the ratio of small to large tubers." 
TABLE B.

Showoing the Results of of the Use of Commorcial Ferrilizers, in Produetion, Profit and hoss.s, in Growing l'statoes.

\begin{tabular}{|c|c|c|c|c|c|c|c|c|c|c|c|c|c|c|c|}
\hline \multicolumn{3}{|c|}{ Fertilizers Tsed. } & \multicolumn{7}{|c|}{ Lurly liose. } & \multicolumn{6}{|c|}{ White Star. } \\
\hline$\stackrel{\Xi}{\Xi}$ & 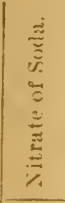 & 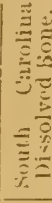 & & $\stackrel{\Xi}{\Xi}$ & 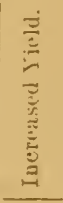 & 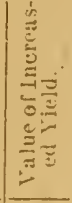 & 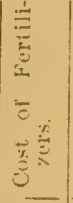 & 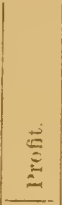 & 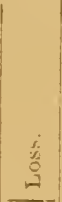 & $\stackrel{\partial}{\ddot{Z}}$ & 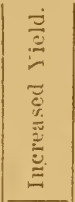 & 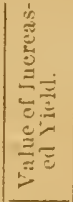 & 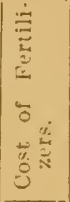 & 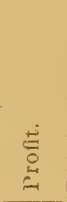 & $\stackrel{3}{9}$ \\
\hline L,bs. & $1.6 s$. & LW: & & Los. & L6S. & Crs. & Cls. & Cts. & CLs. & Lbs. & Lbs. & Cts. & Uts. & Cts. & \\
\hline $4:$ & & & & 48.7 & $: 21: 2$ & 15.16 & 7.66 & 10.50 & & 58.1 & 19.1 & $17.3 \pi$ & 7.67 & 9.7 & \\
\hline & S.3: & & & $3 \pi .5$ & 10.0 & 8.33 & 13.91 & & 58 & 53.4 & 14.4 & 13.25 & 13.91 & & \\
\hline $4: 2$ & & & & 45.5 & 18.0 & 14.74 & 12.42 & 2.35 & & 22.0 & 33.0 & 28.95 & 12.42 & 16.53 & \\
\hline $4: 2$ & $\begin{array}{r}8.38 \\
\text { ing. }\end{array}$ & & & $\begin{array}{l}27.0 \\
27.5\end{array}$ & -0.5 & 1.33 & 18.67 & & 17.31 & 58.8 & 19.8 & $17.6:$ & 18.6 & & \\
\hline 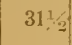 & & & & 25.6 & -1.9 & -0.21 & 5.77 & & 5.98 & 35.9 & -3.1 & -0.87 & 5.87 & & \\
\hline $31 \frac{1}{2}$ & 8.33 & & & 30.0 & .5 & 2.73 & 12.02 & & 9.29 & 30.6 & -8.4 & -5.41 & $1: 02$ & & 17 \\
\hline $31 \frac{1}{2}$ & & 2 & & 44.0 & 16.5 & 10.39 & 10.58 & & 0.13 & 51.6 & 12: 6 & 11.95 & 10.52 & 1.43 & \\
\hline $31 \div 2$ & 8. 33 & 2 & & 40.3 & 12.8 & 8.66 & 16.77 & & 8.11 & 56.1 & 17.1 & 15.55 & $16 . \pi$ & & \\
\hline 21 & & & & 21 & -3 . & -3.25 & 3.83 & & 7.11 & 23.4 & -16.6 & -10.86 & 3.83 & & 11. \\
\hline$a_{1} b_{1}$ & ing. & & & 35.3 & 7.8 & 5.61 & & 5.64 & & 38.4 & $\mid-0.6$ & $\mid-0.15$ & & & \\
\hline
\end{tabular}




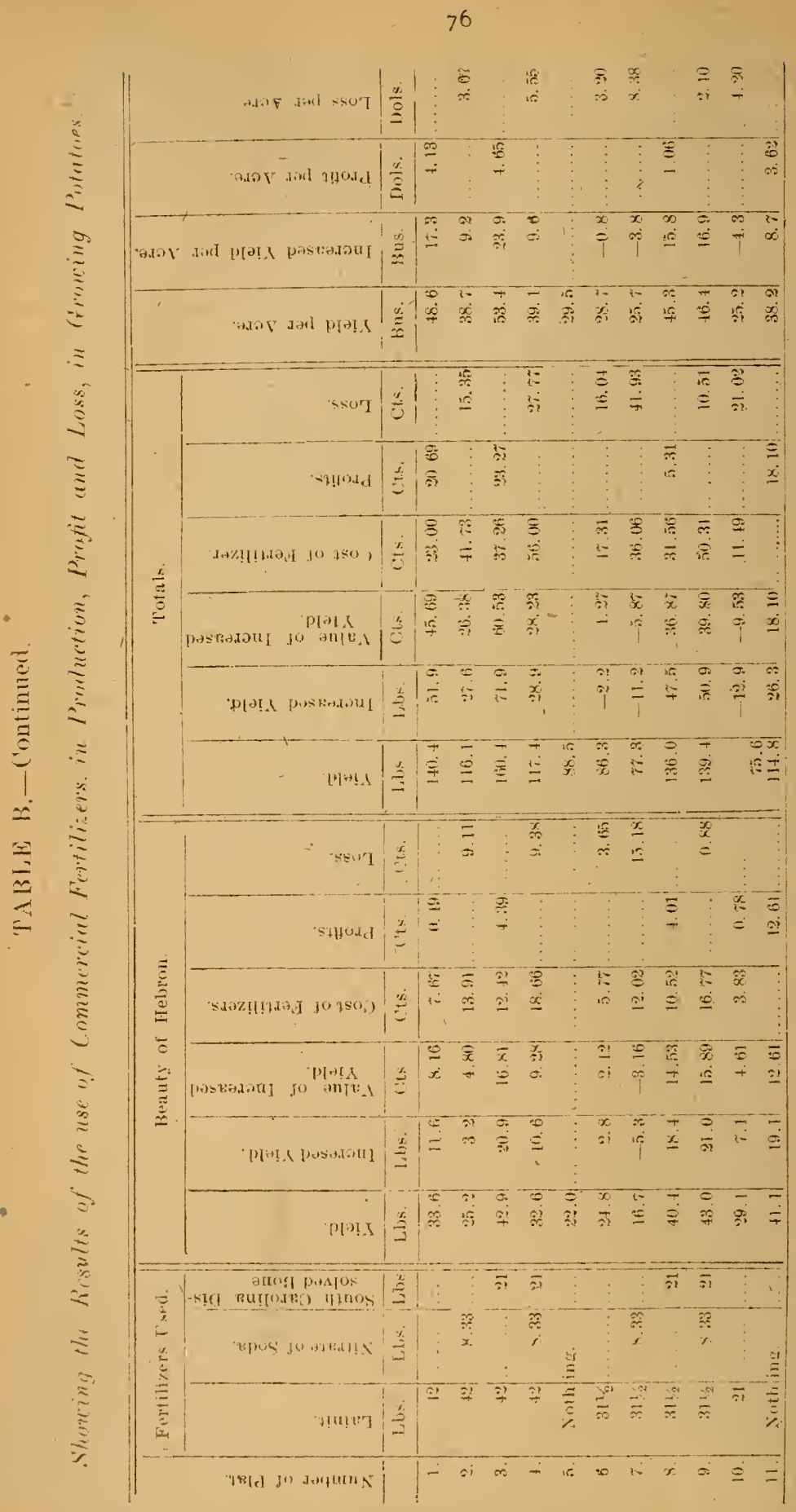


11. The increased yield produced by the use of commercial lertil izers, and the profit and loss in the use of the same.

Table $B$ shows the amount and cost of the fertilizers used, the yield and the increased yield produced by the use of fertilizers; the value of the increased or decreased (-) yield (estimating the value of the large tubers at fifty cents and the small one at twenty cents per bushel) and the profit and loss of fertilization of each variety on each plat, and the increased yield, profit and loss per acre.

Here again, we have a remarkable agreement with the facts brought out in the experiment of $189 \mathrm{r}$. Plat No. 5, without any fertilization produced $88 \mathrm{x} / 2$ pounds, while Plat 1, with 42 pounds of Kainit produced I 40.4 pounds. In Plat 2, to the Kainit, we added $81 / 3$ pounds of Nitrate of Soda and decrease the yield 24.3 pounds, but have an increase over the unfertilized plat of 27.6 pounds. In Plat 3 , by adding to the Kainit 2 I pounds of $\mathrm{S}$. C. Dissolved $B$ sne, we increase the yield to 160.4 pounds, an increased yield of 20 pounds over plat 1 , and an increase of 71.9 pounds. or 81.24 per cent. over the unfertilized plat. We add $8 \frac{1}{3}$ p punds Nitrate of Soda to the amount of fertilizer applied to Plat 3, thus making a "complete fertilizer" and apply it to Plat 4, resulting in a yield of II7 4 pounds, an increased yield over the unfertilizad plat of 289 pounds, but a decreased yield from Plat 3 of 43 pounds.

Taking plats $6,7,8$, and 9 we find a slight variation from the results of $189 \mathrm{I}$. Plats 6 and 7 falling below the yield of the unfertilliz:d plat. In Bulletin No. 20, page 132 , it is stated "That part of No. 6, on which the Early Rose were planted, and the whole of No. 7 was very poor. Here is strong evidence of the exhaustion of the small amount of flant food naturally existing in this soil by the crop of $189 \mathrm{I}$, Our estimate of the natural fertility or rather natural sterility of this soil in the former experiment is fully sustained by the experiment of 1892 . Taking plats 8 and and 9 , on which the natural fertility was nearly the same as on Plats $I, 2,3$ and 4 we find the effects of the fertillizers to bo very nearly what they were in ISgI, the yields in plats 8 and 9 are much below the yields in plats 3 and 4 for both years, which it is believed are fully accounted for by the reduction of one-fourth in the amount of potash fertilizers applied to these plats. It will be observed that in both years, plat 3 produced a larger yield than plat 4, while plat 9, corres. ponding with plat 4 , produced a larger yield than plat 8 which corresponds with plat 3. It was stated in the former bulletin that plat 9, probably contained the most fertile spot in the entire series of plats. This statement seems to be fully sustained by the last exveriment and explains the abnormal increased yield of that plat.

To the ten plats of $189 \mathrm{r}$. was added Plat I in I892. Plat I I adjoins Plat 10, and when the soil was "broken up" in March, r 89r, there was no perceptible difference in the natural fertility of the soils of these two plats. They were both yellowish gray clay soil containing but very little humus. Both plats were broken up at the same time, and while Plat ro was fertilized with 2 I pounds of Kainit and a crop of potatoes grown upon in $189 \%$, Plat I I remained 
idle, and was cultivated only sufficiently to keep down the weeds. No fertilizers were applied, and no crop was grown upon Plat I i in the year 189 , it being a vacant strip between the last potato plat and the tomato plats adjoining, and was used as a "turning row." In the spring of $18{ }^{2}$, it was again "broken up" and planted in potatoes at the same time and in the same manner and received the same cultivation as the other plats.

No fertilizers, whatever, were applied to Plat in, yet it produced II 4 pounds of potatos, while the other unfertilized plat (No. 5) which had produced in $189 \mathrm{I}, 244.5$ pounds of potatoes, only produced 885 pounds. Now, supposing the natural fertility of the soils in plats 5 and I I were the same in I8gt (we are convinced that the natural fertility of the soil on Plat i i was much below that of Plat 5, in $18 \mathrm{~g}$ ) by comparing the yield of these two plats for the year $x 892$, the. wonderful effect of the exhaustion of the plant food naturally contained in a slightly recuperated, "worn out" soil by the production of a single crop becomes strikingly apparent. But this effect becomes much more marked if we compare Plats ro and i i, making even a very small allowance for the effect of the fertilizer applied to Plat ro. The supreme folly of attempting to renovate a a worn-out soil by the use ot commercial fertilizers alone, while cultivating the soil and removing the crops therefrom, is here so c early demonstrated that it needs no further argument.

The profit and loss account is fully set forth in the table, but is rendered almost valules; by the failure of the crop; but even under these circumstances, we find that the use of potash and phosphoric acid combined, gave us, on Plat 3 , a net profit at the rate of $\$ 4.65$, and on Plat 8 , a net profit at the rate of \$1.06 per acre. The Kainit Plats, Nos. 5,6 and $x 0$, in one respect, show the same comparative results as in $18 \mathrm{gI}$-Plat I showing the largest, and Plat io the smallest yield, but the difference is much greater in, 892 than in 189I. In the crop of 1892 , the net profit on Plat I is at the rate of $\$ 4$. I 3 per acre; on Plat 6 , a loss of. $\$ 3.20$, and on Plat 10 , a loss of $\$ 4.20$ per acre. We are satisfied that this difference was not caused wholly by the difference in the amount of Kainit applied to each of these plats, but is to a large extent attributable to the difference in the natural fertility of the soil. The Nitrate of Soda, as in the experiment of $\mathrm{r} 8 \mathrm{~g}$ i seems to have had no beneficial effect whatever. 


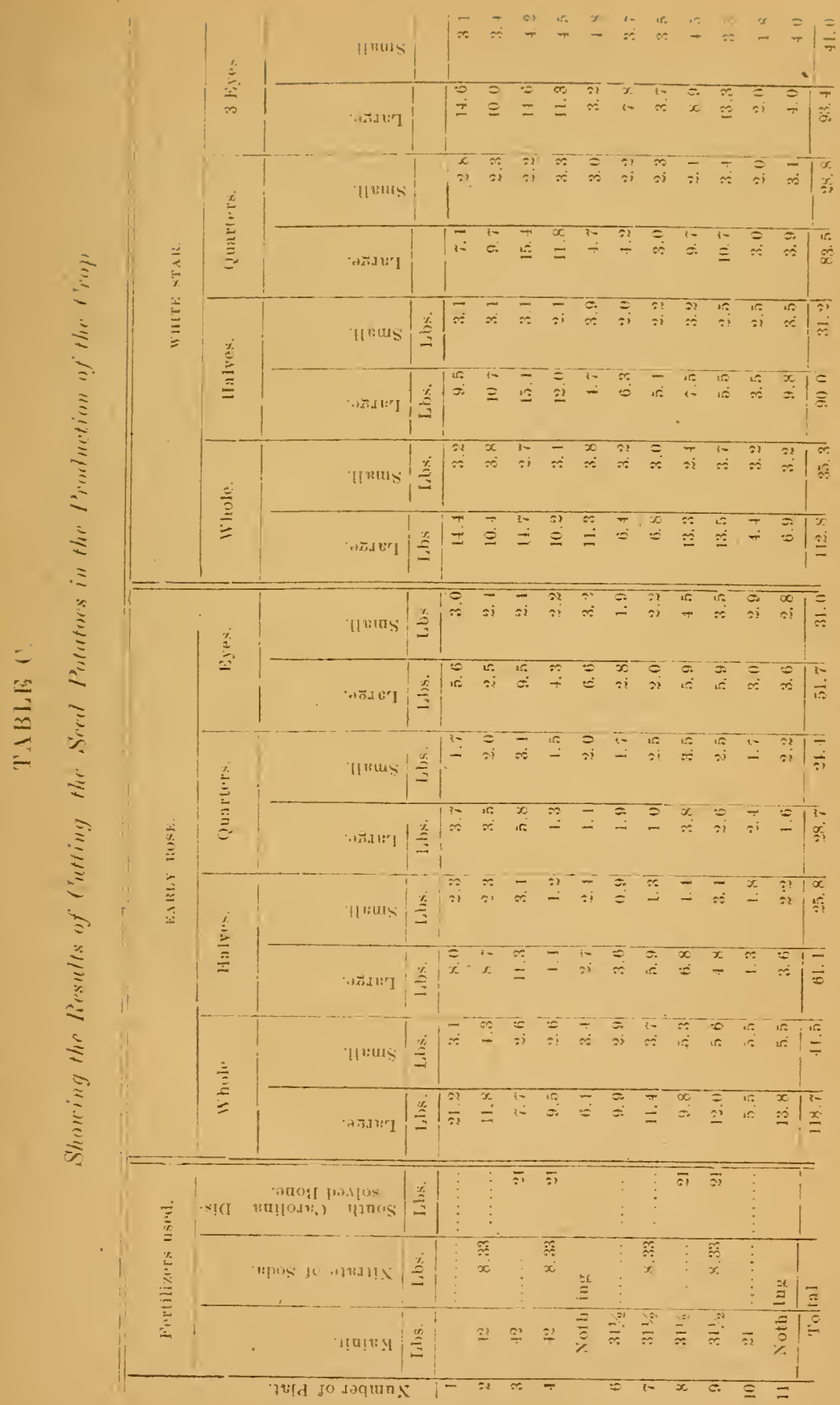




\section{0}

TABLE C:- Continued.

\begin{tabular}{|c|c|c|c|c|c|c|c|c|c|c|c|c|c|c|}
\hline \multirow{4}{*}{$\begin{array}{l}3 \\
\vdots \\
3\end{array}$} & \multicolumn{2}{|c|}{ Fertilizer } & \multirow{3}{*}{ 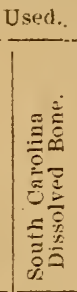 } & \multicolumn{8}{|c|}{ Beauty of Hebron. } & \multirow{2}{*}{\multicolumn{2}{|c|}{ Total. }} & \multirow[b]{3}{*}{$\begin{array}{l}\bar{z} \\
\frac{3}{0} \\
\dot{0}\end{array}$} \\
\hline & & & & \multicolumn{2}{|c|}{ Whole. } & \multicolumn{2}{|c|}{ Halves. } & \multicolumn{2}{|c|}{ Qu:zrters. } & \multicolumn{2}{|c|}{ 3-Eyes. } & & & \\
\hline & $\stackrel{\bar{\Xi}}{\underline{\Xi}}$ & 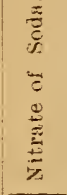 & & 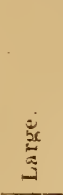 & 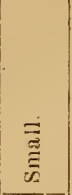 & 离 & 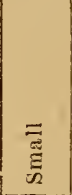 & 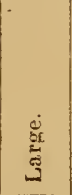 & 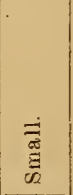 & 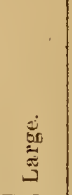 & 部 & 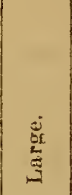 & 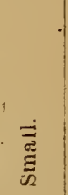 & \\
\hline & Lbs. & Lbs. & Lhs. & Lbs. & $L b s$ & Lbs. & Lbs. & Lbs. & Lbs. & Lbs. & Lbs. & Lbs. & Lbs. & Lbs. \\
\hline 1 & 42 & $\cdots$ & & 5.1 & $\overline{3.2}$ & 4.9 & 3.2 & 5.2 & 2.8 & 5.8 & 3.4 & $\overline{105.4}$ & $34 . \overline{9}$ & $\overline{140.3}$ \\
\hline$\Rightarrow$ & $4 \%$ & 8.33 & 3 & 6.9 & $1 . \tau$ & 3.9 & 0.9 & 2.9 & 1.4 & 5.7 & 2.8 & 86.7 & 30.4 & 117.1 \\
\hline 3 & $4: 2$ & & 21 & 5.1 & 2. 7 & 5.3 & 1.9 & 6.1 & 1.8 & 14.8 & 4.2 & $1: 26.4$ & 31.0 & 160.4 \\
\hline 4 & 42 & 8.33 & $\approx 1$ & 13.4 & 2.1 & 3.0 & 1.1 & 4.0 & 1.9 & 3.7 & 3.4 & $89 .:$ & 29.0 & 118.4 \\
\hline 5 & Yoth & $\operatorname{lng} g$ & & 4.0 & 2.8 & 3.2 & 2.1 & 1.2 & 1.0 & 4.2 & 3.5 & 53.0 & 35.5 & 88.5 \\
\hline is & $31 \frac{1}{2}$ & & & 5.7 & 2.2 & 1.9 & 1.7 & 1.9 & 2.2 & 5.4 & 3.8 & 5.8 & 28.5 & 86.3 \\
\hline 7 & $311 / 2$ & 8.33 & & 4.0 & 2.4 & 2.8 & 1.8 & 0.7 & 0.8 & 2.3 & 1.9 & 48.7 & 28.6 & 77.3 \\
\hline 8 & $311 / 2$ & .... & 21 & 7.5 & 4.1 & 4.7 & 1.4 & 3.3 & 2.2 & 13.9 & 3.3 & 95.1 & 40.9 & 136.0 \\
\hline 9 & $311 / 2$ & 8.33 & & 9.8 & 2.7 & 6.7 & 2.1 & 6.8 & 2.6 & 7.1 & 5.2 & 98.7 & 40.7 & 139.4 \\
\hline 10 & $\approx 1$ & & & 4.2 & 2.8 & 3.2 & 1.3 & 3.4 & 3.3 & 6.3 & 4.6 & 42.2 & 33.4 & 75.6 \\
\hline 11 & Noth & ing & & $\tilde{5} . \overline{5}$ & 2.8 & $\pi .4$ & 5.4 & 5.1 & 3.0 & 7.1 & 4.8 & 72.3 & 12.5 & 114.8 \\
\hline & otal & $\ldots$ & & 72.2 & 29.5 & 47.0 & 22.9 & 40.6 & 23.0 & 76.3 & 40.9 & & $\ldots$ & $\ldots \ldots$ \\
\hline
\end{tabular}


The comparative yield of large and small potatoes by planting the tubers whole, in hälves, quarters, and cut to one eye in each piece.

- From an examination of the footings of the columns in Table C. it appears that in the Early Rose and White Star varietres the whole potatoes produced the greatest amount of large tubers, and thequarters the least. In the Early Rose, the halves produced morelarge potatoes than either the quarters or single eyes, while in the White Star the single eyes produced more than either the halves or quarters. In the Beauty of Hebron variety, the single eyes produccd the greatest amount of large tubers, the whole, halves and quarters following in the order named. In the experiment of $189 \mathrm{I}$, the Beauty of Hebron was the only variety in which the whole potato produced more than the single eyes. In the racord of that expeirment the following statement appears: "The table in the case of the Beauty of Hebron seems to favor the planting of the whole potato, but it is believed that under the same conditions, the same results would appear, as in the Early Rose and White Star." In the experiment of 1892 , the same conditions were secured by making the rows a little closer together, thus avoiding the "old stony fence row," and the results show the correctness of the opinion then expressed. If we take into consideration the nourishment supplied by the "seed" tubers to the plants produced by the whole potato during their early growth, and at the time the change was being made in the source of plant food and charge the plants produce 1 by the whole potato with this advantage, we believe the re. sults secured by cutting the seed potato will agree, in almost every particular, with that obtained in the experiment of $189 \mathrm{I}$.

It is almost the invariable rule that the greater the yield, the less is the ratio of small to large potatoes, therefore, th it method of preparing the seed and planting, and the method of fertilizing which will produce the largest yield, and pay for the fertilizer used, are the methods which stould bə followed.

Table D. shows the yield, the increased yield and the per centage of increased yield for the two years, and will help the reader in comparing results. 
TABLE D.

Showing the Yield, Increased Field and Percentage of Incrensed Field for the Yeurs 1891 and 1892.

\begin{tabular}{|c|c|c|c|c|c|c|c|c|c|}
\hline \multirow[b]{2}{*}{ 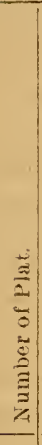 } & \multicolumn{3}{|c|}{ Fertilizers $\Lambda$ ppleed. } & \multirow[b]{2}{*}{ 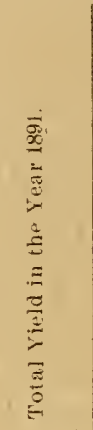 } & \multirow[b]{2}{*}{ 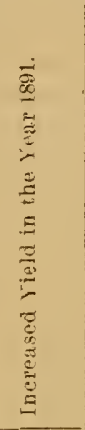 } & \multirow[b]{2}{*}{ 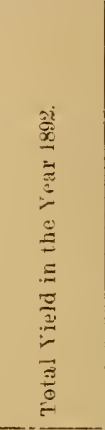 } & \multirow{2}{*}{ 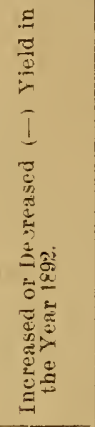 } & \multirow{2}{*}{ 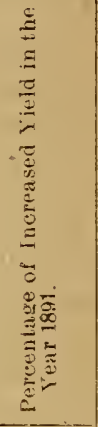 } & \multirow{2}{*}{ 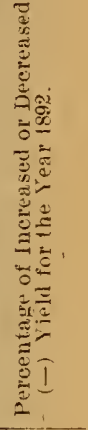 } \\
\hline & $\stackrel{\Xi}{\Xi}$ & . & 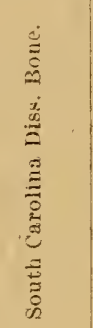 & & & & & & \\
\hline & Lbs. & Lbs. & Lbs. & Lhs. & Lbs. & Lbs. & Los. & & \\
\hline 1 & 42 & & & 332.25 & 87.75 & 140.40 & 51.90 & 35.78 & 58.64 \\
\hline 2 & 42 & - 8.33 & ... & 350.75 & 106.25 & 117.10 & $2 \pi .60$ & 43.45 & 31.18 \\
\hline 3 & 42 & .. & 21.00 & $5: 0.50$ & 226.00 & 160.40 & $\pi 1.90$ & 112.88 & 81.24 \\
\hline 4 & 42 & 8.33 & 21.00 & 445.00 & $\approx 00.50$ & 118.40 & 28.90 & 82.00 & 32.65 \\
\hline 5 & Noth & ing. & . & 244.50 & $\ldots$ & 88.50 & & & \\
\hline 6) & 31.50 & & $\ldots$ & 311.25 & 66.75 & 86.30 & -2.20 & 8.30 & $-0: 48$ \\
\hline$T$ & 31.50 & 8. 33 & $\ldots$ & 271.75 & $2 \pi .25$ & 7.30 & -11.20 & 11.14 & -1265 \\
\hline 8 & 31.50 & & 21.00 & 425,75 & 181.010 & 136.00 & +7.50 & 74.02 & 53. 65 \\
\hline 9 & 31.50 & 8.33 & 31.00 & 462.25 & $21 \% \pi$ & 189.40 & 50.50 & 89. $46^{\circ}$ & $5 \tilde{7.51}$ \\
\hline 10 & 21.00 & & & $260 .(00)$ & $23 . i 5$ & 75.60 & -12.90 & 09.71 & -14.55 \\
\hline 11 & Noth & ing. & & & & 114.80 & & & 29.71 \\
\hline
\end{tabular}


Taking the experiments of 1891 and of 1892 together, we find a very remarkable agreement, even to minute details, and from the results of these experiments, confining pur conclusions to the peculiar character and conditions of the soil upon which the experiments were conducted, we conclude that the best results in commercial fertilization, as tested, will be secured by a combination of Potash and Phosphoric Acid in the ratio of 2 to 1 .* That there is no material beneflt, but an actual loss in the use of Nitrate of Soda; that the best results in the preparation of the "seed" can be secured by so cutting the tubers that each piece will produce one strong vigorous stalk, and by planting from two to four pieces in each hill, according to the distance the r.ills are apart.

\section{Experiments in the Use of Commercial. Fertilizers in Growing Corn at the Several Out-Stations.}

In obedience to the order of the Board of Regents, Out-Stations for experimental purposes were established in different parts of the State as follows: One at Martinsburg, in the county of B rkeley; one near Buckhannon, in the county of Upshur; one at Selden, in the county of Wood, and one near Buffalo, in the county of Putnam. One acre at each of the out-stations in Berkeley, Wood and Putnam, and three-fourths of an acre in the county of Upshur were set apart for experiments in growing corn. The land at each of the stations ir the counties of Berkeley, Wood and Putnam was divided into sixteen plats, each plat being one rod wide and ten rods long and containing one-sixteenth of an acre. The land in Upshur was divided into fifteen plats, eash one rod wide and eight rods long, containing one twentieth of an acre. The experiments on these plats are being conducted for the purpose of determinin the comparative merits of Kainit, Muriate of Potash and Sulphate of Yotash as potash fertilizers in growing corn. The plats were divided into three series of four plats each. Four plats at each station were unfertilized and reserved as "checks" to determine the effects of the fertilizers on the others. As a basis from which to calculate the increased or decreased yield, the yields of the two unterfilized plats on each side of and adjacent to each series, were added together and divided by two. The fertilizers were applied when the corn plants were about three inches high, by sprinkling one-half of it along the rows and sowing the other half broadcast over the plats.

*NotE.-In this experiment we have used Kainit, containing 14 per cent. uf Potash; ${ }_{+}$DissolvediBone cos taining 14 per cent. of Phosphoric Aeid, and Nitrate of So la, containing 15 per cent. of Nitrogen, and applied it at he rate of 8101 bs. of Kainit, 420 lbs. S.C. Dissolved Bone and $106 \% / 3 \mathrm{bs}$ of vitrate of Soda per acre. Th is $l$, rmula gives us at the rate per acre on Plat 1, $117.61 \mathrm{bs}$. of Potash. On Plat 2, 117.ti 1bs. of Potash and $25 \mathrm{lbs}$. of Nitrogen. On Plat 3, $117.6 \mathrm{lbs}$. of Potach and $58.8 \mathrm{lbs}$ of Phosphoric: Acid, and on Plat 4, 117.6 lbs. of Potash, 25 los of Nitingen and 55.8 . hs. of Pho phoric Acid. If Ifuriate of Potash containing 50 per ceat. of potash, or Sulubate of Potash col taining 25 or 50 per cent. of Potasli is used, it will require a mucis less quantity to furnish the requisite amount of Potash; and the samerule will apply to ald fertilizers. 
In determining the actual amount of potash, nitrogen and phosphoric acid which was applied to each plat, it is necessary to know that the Kainit used contained $1_{4} \%$; the Muriate of Potash $50 \%$ the Sulphate of Potash nearly $52 \%$ of Potash. The Dried Blood contained $12 \%$ of nitrogen and the South Carolina Dissolved bone $14 \%$ of Phosphoric Acid. The tables show the amount and kind of each fertilizer used.

The long continued drouth in the courties of Berkeley and Upshur has so materially affected the results of the experiments in these counties as to render them almost valueless, standing alone. Unless we should supply the necessary moisture by irrigating adjacent plats, it is impossible to determine with any degree of accuracy the effects which were caused by the drouth. Comparing this with the crops of other years, omitting altogether the factor of fertilization, we know that the effects have been very disastrous. Farmers are well aware of the fact that a liberal application of fresh stable manure, followed by a dry season, often proves very injurious to the growing crop, causing what is known as "burning out." In the experiments under consideration, it seems that the use of commercial fertilizers has generally produced the same effect and prov. ed injurious to the growing crop. Had the required conditions of moisture been fulfilled, the results of fertilization, no doubt, would have been radically different and very satisfactory. We regret that we have no record of the temperature and rainfall at any of these out-stations, save one, as such data would enable us to trace more accurately the effects of drouth, and the effects of fertilization accompanied by drouth. These experiments emphasize the remarks of Prof. A. W. Harris in the Experiment Station Record of January, $\mathrm{I} \$ 93$ in regard to the importance in all such tests of accura. tely noting the temperature of the atmosphere, the moisture and other physical conditions of the soil.

We are apt to conclude that an experiment is a failure if it does not produce the beneficial results anticipated. There is some reason for this conclusion anong farmers who are looking alone for immediate profits and are not seeking for scientific facts which will enable them to understand and make available the laws of nature, which govern every profitable investment in agriculture. A failure is often as valuable as a success, as it is as important to know what not to do as to know what to do, and if we do the proper thing, and the results are not satisfactory, we desire to know why? 
TABILE E.

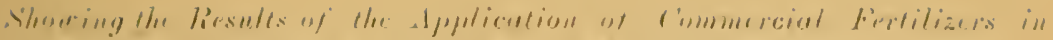

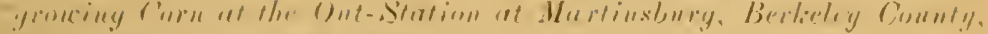

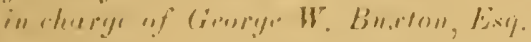

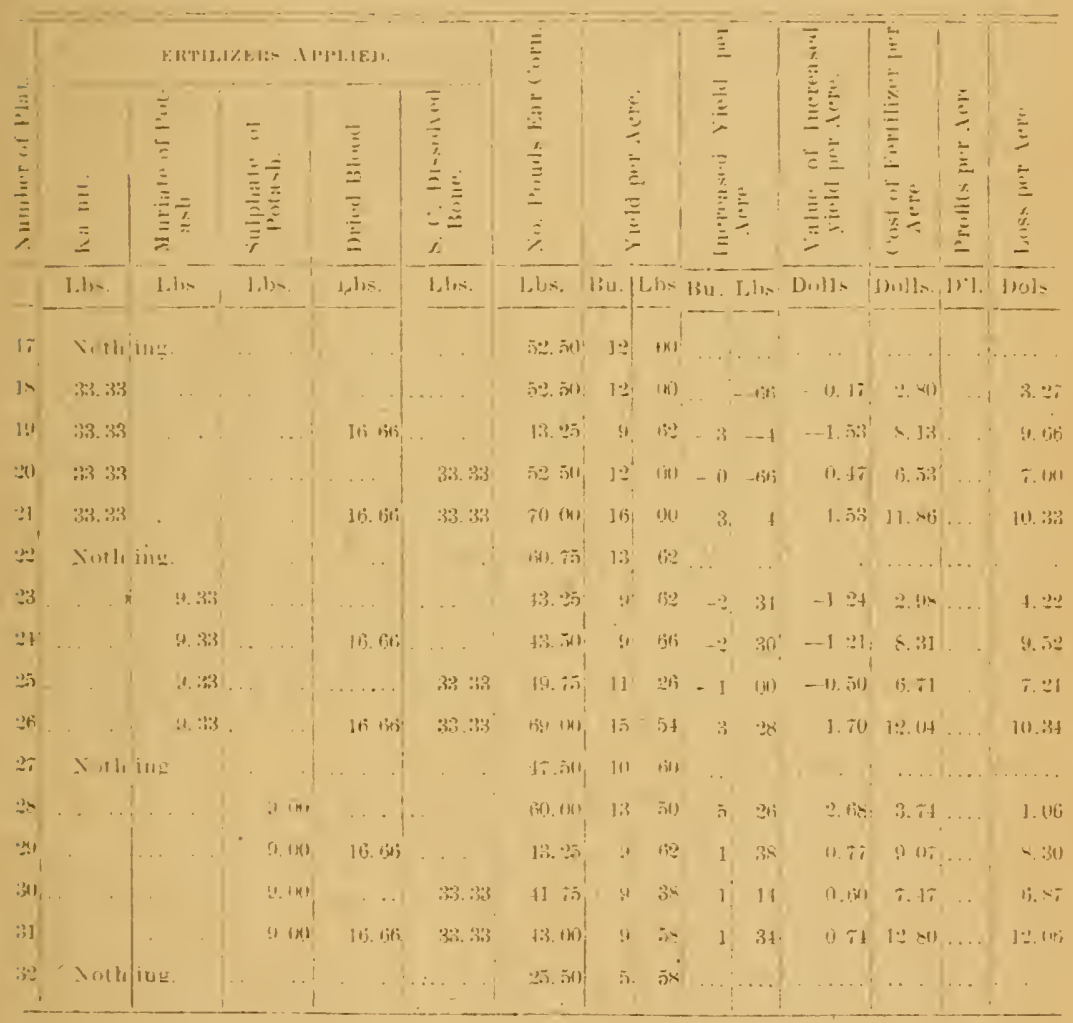


At the out-station in Berkeley, the drouth began early, and con. tinued almost throughout the season.

By an inspection of Table E., it will be seen that the yield on one-half of the fertilized plats is below that of the unfertilized plats; the average decreased yeild being $\mathrm{x} .9$ bushels, while the average increased yield of the other half of the fertilizers plats is 267 bushels per acre. The largest decreased yield is on plat 19, where we have a combination of Kainit and dried blood, being at the rate of 3 bushels and four pounds per acrt, while the smallest decreased yield is on plat 18 , where we used Kainit alone, and on plat 20 where we combined Kainit and S. C., Dissolved Bone being at the rate of 66 pounds of corn per acre. The increased yield of the first two series of plats, the first where Kainit, and the second where Muriate of Potash is used to supply the potash. is confined to the plats on which the comple fertilizers were used, Nos. 2I and 26. Yet these two plats have a higher rate of loss per acre than any of the other plats in these two series. The total decreased yield of each of the first two series of plats is very nearly the same; the Kainit plats being 2 bushels and $4 \mathrm{I}$ pounds, and the Muriate of Potash plats being 2 $\mathrm{b}$ :shels and 36 pounds. There is an increased yield on all of the third seies of plats where the potash fertilizer is supplied by Sulphate of l'otash, the most remarkable increase being on plat 28 , where Sulphate of Pot sh alone is used. There is a very small difference in the increas 4 yield of the other plats of the third series. The addition of Dried Blcod and S. C.. Dissolved Bone, either separa.ely or combined seeming to have but little effect, and the complete fertilizers in this case did not produce the marked effect which it did on plats 2 I and 26 .

The average yield. of the plat upon which Kainit was used as a fertilizer is at the rate of 12 bushels and 33 pounds per acre.

The average yicld of the plass upon which Muriate of Potash was used as a fertilizer, is at the rate of I I bushels and 52 pounds per acre.

The average yield of the plats upon which Sulpbate of Potash was used as a fertilizer ts at tice rate of 10 bushels and 52 pounds per acre

The cost of the potash fertilizers was: Kainit $\$ 2.80$, Muriate of Potash $\$ 2.98$, Sulphate of Potash $\$ 3.74$ per acre. 


\section{7 \\ T. IBLA F.}

Shoring the litsults of the dputication of Commereint Fertilizers in Cromeing Com at the Ont-Stution at Buclibumon, L'pshur County, in chargenf $\mathrm{Hl}$ lin $\mathrm{H}$, Ligget, Esq.

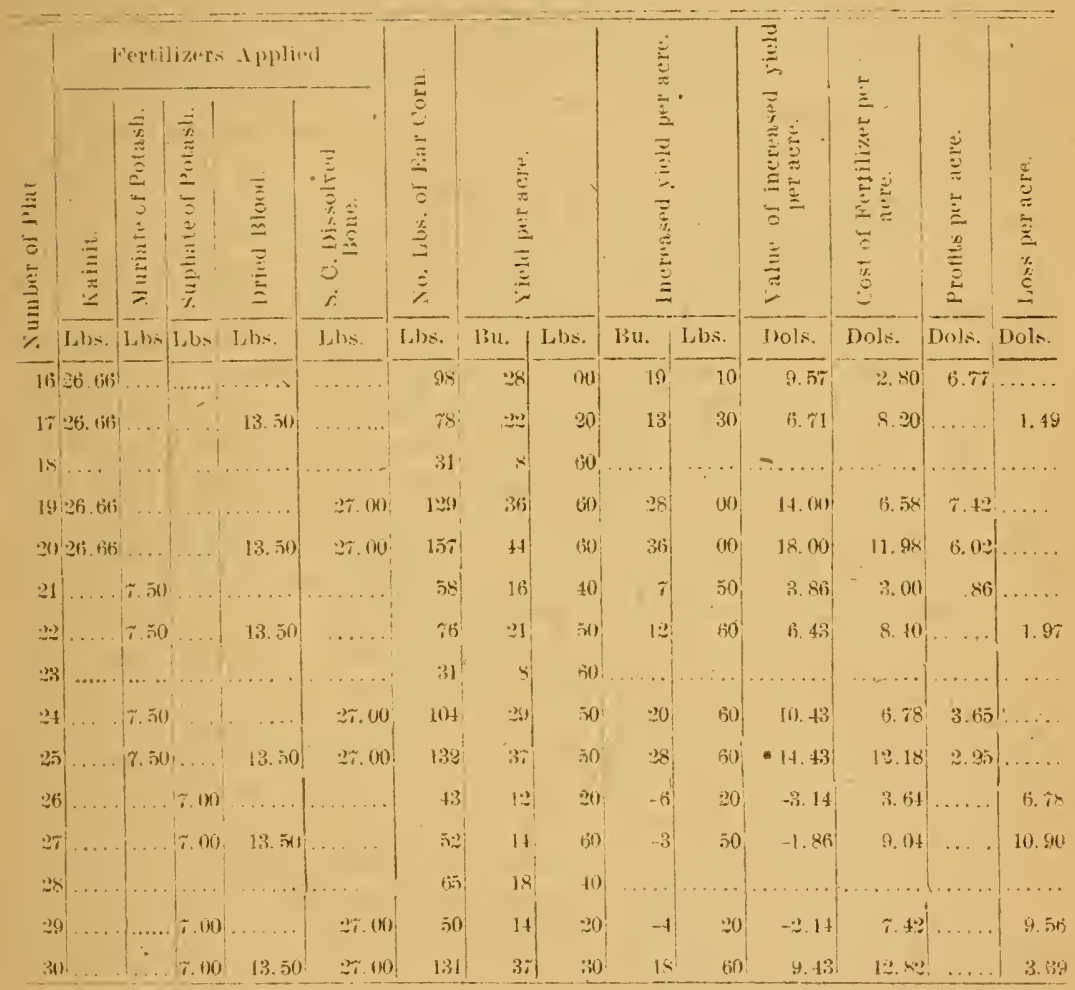


In the experiment in Upshur county, the plats are eight rods long and one ror wide and contain eight square rods or one-twentieth of an acre exch, and are laid off in three series of five plats each; the middle plat of each series being unfertilized. In the calculations the yield of the unfertilized plat is made the basis, and the increased or decreased yield ${ }^{3}$ of all the fertilized plats in each series are de. termined by the difference between the fertilized and unfertilized plats of that series. These plats are all on a hillside having a southeastern exposure. The soil is a dark red clay loam, and was in pasture last year. The latter part of the season was very dry, there being no rainfall after the 20 th day of July until after the crop had matured.

By reference to the table, we find that in the first series of plats where Kainit was used to supply the potash fertilizer, Kainit alone on plat 16 increased the yield 19 bushels and ro pounds. By the addition of $x_{3}$ and $1 / 2$ pounds of dried blood (plat $\times 7$ ) the increased yield is reduced to 13 bushels and 30 pounds, depriving us of the profit of $\$ 6.77$ per acre which plat 16 gave us, and creating an actual loss of \$I.49, the whole injury amounting to $\$ 8.26$ per acre. On plat 19 , we $a$ add to the Kainit 27 pounds of S. C. Dissolved Bone, and secure an increased yield over the unfertilized plat at the rate of 28 bushels, and an increased yield over plat 16 at the rate of 7 bushels and 60 pounds worth $\$ 3.93$ at an expense of $\$ 3.73$ (the cost of the S. C. Dissolved Bone used), leaving a net profit of $20 \mathrm{cts}$. per acre in the use of the S. C. Dissolved Bone.

On plat 20 where all three of the fertilizers are applied, we have an increased yield at the rate of 36 bushels per acre, giving us, by the application of dried blood, an increased yield over plat 19 at the rate of 8 bushels per acre worth $\$ 4.00$. The Dried Bloood cost at the rate of $\$ 5.40$ per acre thus causing an actual loss by its application of $\$ \mathrm{~T} .4 \mathrm{O}$.

In the second series of plats where Muriate of Potash is used to supply the potash fertilizer, we find that muriate of potash alone (plat 2I) gives an increase yield at the rate per acre of 7 bushels and jo pounds and a net profic of 86 cents per acre.

By the addition of dried blood (plat 22) we have an increased yield of 12 bushells and 60 pounds per acre, but an actuul loss of $\$ 1$ g7 per acre, causing an actual loss of $\$ 2.83 p \in \mathrm{r}$ acre. On plat 24, we have used Muriate of Potash and S. C. Dis. Bone combined, and have an i! creased yield at the rate of 20 bushels and 00 pounds. By this combination, we have an increased yield over plat $2 \mathrm{I}$ at the rate of 13 bushels and ro pounds worth $\$ 6.57$. The S. C. Dissolved Bone cost at the rate of $\$ 3.78$ per acre; hence, we have a net profit by reason of this combination of $\$ 2.79$ per acre. On plat 25 , we agaiu combine the three kinds of fertilizers, and have an increased yield over plat $2+$ of 8 bushels, being exactly the same increased yield for the addition of the dried bload that we obtained in plat 20 , and the same net loss by its use of \$ I 40.

In the third series of plats, we encounter several difficulties which are inexplicable. By a very close inspection, it was impos- 
sible to discover any material difference in the natural fertility of the soil on any of the three series of plats, yet the unfertilized plats of the first two series produced at the rate of eight bushels and 60 pounds each per acre, while the unfertilized plat of the third series produced at the rate of 18 bushels and 40 pounds per acre or more than twice as much. Notwithstanding the apparent increase of the natural fertility of the soil in the third series of plats, as shown by a comparison of the yields of plars 18 and 23 with plat 28 , we find that all of the fertilized plats of this series, except plat 30 , failed to producz as much as the unfertilized plat, and fell far below the yield of any of the other fertilized plats. Did the application of Sulphate of Potash to these plats cause this decrease? On plat 26 the application of Sulphate of Potash alone gives us a decreased yield at the rate of six bushels and 20 pounds per acre. On plat 27 , by adding the Dried Blood, we increase the yield over plat $26,{ }^{\prime} 2$ bushels and 40 pouncs, but have a decreased yield from plat 28 of 3 bushels and 50 pounds per acre. By adding S. C. Dissolved Bone to the Sulphate of Potash on Plat 29, we have an increase over plat 26 of 2 bushels per acre, but a decreased yield from the unfertilized plat of 4 bushels and 20 pounds per acre Here we have recovered a part of the loss sustained on plat 26 by the addition of nitrogen on plat 27 , and the addition of phosphoric acid on plat 29 , but in neither case has the gain been sufficient to pay for the additional fertilizers applied: On plat 30 , we combine the potash, nitrogen and phosphoric acid, and have a very decided increased yield, but not enough to pay for the fertilizers used. As the Sulphate of Potash seems to have had no beneficial effect combined with either Dried Blood or S. C. Dissolved Bone, did it contribute to the increased yield when combined with both? Or should the com. bination of Dried blood and. S. C. Dissolved Bone be credited with the entire increased yield on plat 30 ? We are inclined te think that in this experiment the use of Sulphate of Potash is not only a complete failure, but it is the cause of very serious loss.

The average yield of the plats upon which Kainit was used as a fertilizer, is at the rate of 33 bushels and 15 pounds per acre.

The average yield of the plats upon which Muriate of Potash was used as a fertilizer is at the rate of 26 bushels and 30 pounds per acre.

The average yield of the plats upon which Sutphate of Potash was used as a fertilizer is at the rate of 19 bushels and 50 pounds per acre. 
TABLE G

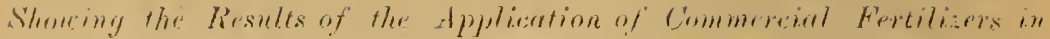
Growing Gown "st the Out-Stufinn at Selden. Woot Conty, in clerrge of S. S'. Stone, Esy.

\begin{tabular}{|c|c|c|c|c|c|c|c|c|c|c|c|c|c|c|c|}
\hline \multirow[b]{2}{*}{ 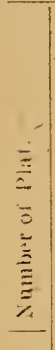 } & \multicolumn{5}{|c|}{ Eertilizers Ipplied. } & \multirow[b]{2}{*}{ 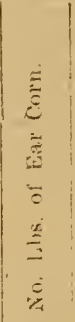 } & \multirow[b]{2}{*}{ 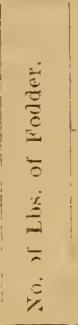 } & \multirow{2}{*}{\multicolumn{2}{|c|}{ 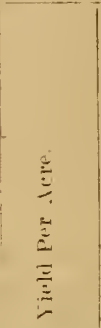 }} & \multirow{2}{*}{\multicolumn{2}{|c|}{ 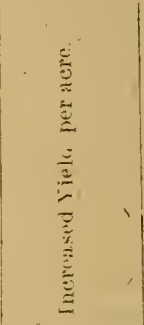 }} & $\underset{\square}{\Xi}$ & 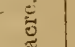 & \multirow[b]{2}{*}{ 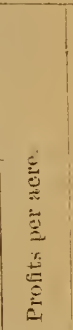 } & \multirow[b]{2}{*}{ 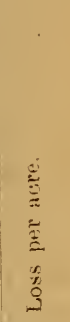 } \\
\hline & 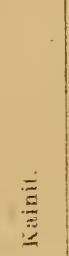 & 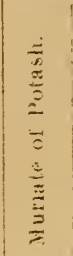 & 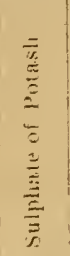 & 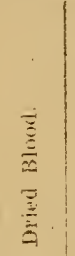 & 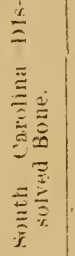 & & & & & & & 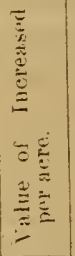 & 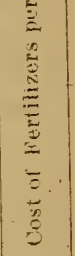 & & \\
\hline & Lbm. & Libs. & $\mathrm{Lb} \cdots$ & Lba. & Lus. & $1,1,5$ & Lbs: & $3 \mathrm{uL}$ & & Bu. & Lb. & Dols. & Dols. & Dols. & Dois. \\
\hline 49 . & Noth & ing: & & & & $1 \times 5$ & 33 & $t^{2}$ & (2)!. & & & & & & \\
\hline 50 & 33.33 & & & & & 219 & 06 & 5!) & 1 & $x$ & wo & +.160 & 2. 80 & 1.20 & \\
\hline 51 & 33.33 & & & 16.06 & & 293 & $2 \pi$ & $66 t^{\prime}$ & $68^{\prime}$ & 24 & is & 12. +5 & 8. 13 & 4.32 & \\
\hline$a e^{\prime}$ & 33.33 & & & & $: 33.33$ & 217 & 256 & 1.9. & 4 & ; & 38 & 3. $\pi$ & 6.53 & & 2.76 \\
\hline 53 & 33.33 & & & 16.66 & 33. 33 & $2 x+40^{\circ}$ & 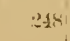 & $65^{\circ}$ & 26 & 3 & $2: 2$ & 11.136 & 11,86 & & 20 \\
\hline ist & Xotls & iug & & & & 1,431 & IKS & 11 & $58 !$ & & & & & & \\
\hline 55 & & 4.38 & & & & sin & 233 & $5 \%$ & $4 x$ & 2 & 44 & 1.31 & 298 & & $1.6 \pi$ \\
\hline 56 & & 4. 32 & & 16.66 & & 355 & 262 & 81 & $1 \times$ & 31 & $1, t$ & 15. (6) & 8.31 & 7.29 & \\
\hline 51 & & $9: 3: 3$ & & & 33.33 & 276 & $3 x-2$ & 53 & 14 & 13 & 30 & 6.57 & 6. 71 & & 14 \\
\hline 58 & & 9.33 & & 16. 615 & 33.33 & sir & 398 & $(n)$ & $5 \%$ & s01 & 45 & $\because 0.34$ & $1 \div 04$ & 8. 30 & \\
\hline 59 & roth & in & & & & ?55 & 2065 & 58 & $2\})$. & & & & & & \\
\hline 60 & & & 9.100 & & & | & ז & 5) & (6) & 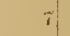 & 30 & $-3 . \pi_{1}$ & 3. 64 & & 7. 45 \\
\hline (3) & & & 4.00 & 16. 66 & & 343 & 53 & th. & 28 & 3) & if & 10. 05 & $y \cdot 0 i \mid$ & .98 & \\
\hline 52 & & & 9.00 & & 33.33 & 189 & 268 & 43 & 14 & -15 & -6 & -7.54 & $\pi .4 \pi$ & & 15.03 \\
\hline 63 & & & 9.100 & 16.56 & 33.33 & $41:$ & 969 & 94 & 20 & 36 & 1) & 18.00 & 12.810 & 5,20 & \\
\hline 64 & $\mid$ Noth $\mid$ & & & & & $301 !$ & 860 & 68 & 56 & & & & & & \\
\hline
\end{tabular}


The out-tation in Wood county, is located at Selden, on the Ohio river, ant is situated on the second or upper bottom lands. The soil is alluvial and consists of a dark sandy loam.

The average yield per acre of the unfertilized plats Nos. 49 and 54 is 42 bushels and 4 pounds. O 3 plat 50 by the application of $\mathrm{K}$ init alone at the rate of 533 pounds per acre, we increase the yiled $S$ bushels and have a $p$ ofit of $\$ r .20$, and on plat 5 c by adding thereto Dried Blood at the rate of $256 \mathrm{r} / 2$ pounds per acre at a cost of $\$ 533$, we increase the yield over plat 50, 16 bushels and 64 pounds, worth $\$ \$ .45$, giving us a net profit by the use of Dried Blood of $\$ 3$ I2. By a combination of the two fertilizers, we have an increased yield of 24 bushels and 64 pounds at a cost for fertilizers of $\$ 813$ and a net profit of $\$ 4.32$ per acre. Un plat 52 , we add to the Kinit, S. C. Dissolved Bone at the rate of 533 pounds per acre, costing $\$ 365$, decreising the yield 32 pounds below the yield of plat 50 where $\mathrm{K}$ init alone was us:d; not only consuming all the profi's of that plat, but causing an actual loss of $\$ 2.76$ on the plat to which it wa; applied, making a total loss on the plat on which it was used of $\$+93$. $\mathrm{O}$ I piat 53 we have a combination of $\mathrm{K}$ tinit, Dried $\mathrm{B}$ ond, and $\mathrm{S}$. $\mathrm{C}$., Dissolved $B$ me, and if we give each of these fertiliz $\lrcorner$ rs credit for what they have produced on plats 50,5 and 52 , refucing the pounds to decima!s at a bishel, we have for the K init 8 bushols. For the Driod Bloo tr 6.91 bushels and for the S. C, Dissolized Bone - 46 bushols. H-nce, we have $S+r 6.9 r-46=24.45$ as the vield of plat 53 But in this calculation, we have made no allowance for the injurinus ffect the S. C. Dissolved Bone had upon the productive powers of the Dried Bloot. Suppose it had the proportional effect on the Dried Blood as we have shown that it hat on the Kainit, then we must charge it with decreasing the productive power of the Dried B ood .96 of a bushel, which added to the .46 would give us I. 42. We then have $8+16.91-1.42=2349$ bushels as the increased yield of plat 53. By ref rence to the table, we find that the actual increase is 23 bushels and 22 pounds, or 23.3 I bushels, a difference of only 18 of a bushel, or 12.6 pounds per acre showing in both cases that the dissolved bone notonly failed to produce any increase, but actually dimished the yield.

In the second series of plats for the potash fertilizer, we have used Muriate of Potash. On platt 55, by the use of Muriate of Potash alone, we increased the yield at the rate of two bushels and 44 pounds per acre, but sustain an actual loss of $\$ 1.76$ per acre. On plat 56 , we add the Dried Blood and increase the yield over plat 55 at the rate of 28 bushels and 40 pounds, and an increased yield over the unfertilized plats at the race of $3 \mathrm{I}$ bushels and 14 pounds per acre. Here, by combining the Dried Bloot with the Muriate of Potash, we not only recover the loss sustained by the use of the latter alone, but have a net profit of $\$ 7.29$ per acre, The combination of S. C. Dissolved Bone with Muriate of Potash, seems not to have had the injurious effect it did when combined with Kainit, but on the contrary has been beneficial by paying for itself and recovering for us nearly all the loss sustained by the use of M:rriate of Potash 
alone (See plats 57, 55 and 52.) It seems to have been still more beneficial when combined with both Muriate of Potash "and Dried Blood, as in plat 58 . But the increased yield of plats 56,57 and 58 may have been caused in part by the increase in the natural fertility of the soil of these plats, and this assumption seems to be strongly supported by the fact that of the two unfertilized plats at the beginning and endiag of this series, the latter (plat 59) produced 6 bushels and 32 pounds per acre more than the former (plat 54). If this assumption should be true, then the apparent increase as the result of the application of S. C., Dissolved Bone, and the apparent superiorily of Murate of Potash over Kainit as a fertilizer, would entirely disappear. Corrected upon the basis of this assumption, the yields per acre of plats 56,57 and 58 would be reduced by about 4, 8 and 12 bushels respectively, giving us a corrected increased yield on plat 56 of 27 bushels and 44 pounds, on plat 57 of 5 bushels and $x o$ pounds, and on plat $5 \%$ of 28 bushels and 48 pounds per acre. L'pon this corrected basis, we find that the Muriate of Potash, as well as the S. C. Dissolved Bone, as applied on plats 55 and 57 , gave no profits whatever, lunt caused an actual loss. while on plats 56 and 58 , the Muriate of Potash combined with Dried Blood, seems to have had the effect of increasing the yield, but it is very duobtful whether such increased yield was sufficient to pay the cost of the potash fertilizer

In the third series of plats, we use Sulphate of Potash to supply the potash fertilizex. From an inspection of plats 60 and 62 it seems that the application of Sulphate of Potash and S. C. Dissolved Bone have each caused a decrease in the yield of each of these plats $z_{t}$ the rate of about $7 \frac{1 / 2}{2}$ bushels per acre. Supposing that the nitrogenous, combined with the potash fertilizer produced the same effect on plat 6 i that it did on plat $5 \mathrm{r}$, which was at the rate of $x 6$ bushels and $6+$ pounds per acre; then we will have on plat 6I an increased yield at the rate of 3 bushels and 14 pounds per acre to be credited to the use cf. Sulphate of Potash when conbined with the Dried Biood. The Sulphate of 'Potash applied to this plat cost $\$ 3.74$; the increased yield of 3 bushels and 14 pounds is worth $\$ 1.60$, leaving a net loss of $\$ 2.14$ caused by the use of Sulphate of Potash.

In plats $6_{3}$ and 64 , we encounter a very important new factor. These two plats were in clover sod at the time the ground was "broken up" at the beginning of these experiments. If we assume that all of the plats of the third series, without the clover, were of the same natural fertility, and that plat 59 truly represents the natural fertilfty (an assumption which we think is well founded) then on plat 64 , which had no other fertilizer. we have for the clover an increased yield of Io bushels and 36 pounds per acre. Now, by subtracting this increased yield caused by the clover, from the yield of plat $6_{3}$, we find the increased yield caused by the commercial fertilizers on this plat to be 25 bushels and 34 pounds per acre. Assuming that the Dried Blood produced substantially the same effect on this plat that it did on the other plats to which it was 
applied, we have for the nitrogenous fertilizer an increased yield of 16 hushels and 64 pounds per acre, which leaves 8 bushels and 40 pounds of the increased yield to he credited to the potash and phnsphoric acid. Assigning the Sulphate of Potash the same increased yield ( 3 bushels and 14 pounds) that we did on plat 61 , we then have on this plat an increased yield of 3 bushels and $1_{4}$ pounds for the Sulphate of l'otash and 5 bushels and 26 pounds for the S. C. Dissolved Bone per acre; neither of which would pay the cost of the fertilizer to which it is credited.

The average yield of the plats upon which Kainit was used as a fertilizer is at the rate of 58 bushels per acre.

The average yield of the plats upon which Muriate of Potash was used as a fertilizer is at the rate of $7 \mathrm{I}$ bushels and 68 pounds per acre, caused, no doubt, by the natural increased fertility of the soil, and to the remarkable effects that Nirrogen produced on this series of plats, and not by the Muriate of Potash.

The average yield of the plats upon which Sulphate of Potash was used as a fertilizer, is 66 bushels and 48 pounds per acre, the increased yield resulting from the same causes as existed in the Muriate plats. 
TABLE H

Shomoing the Results of the Applicution. of Commercial Fertilizers in Growing Corn at the Out-Station at Buffalo; Putnam County in Charge of M. IT. Brown, Esq.

\begin{tabular}{|c|c|c|c|c|c|c|c|c|c|c|c|c|c|c|c|}
\hline \multirow[b]{2}{*}{ 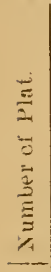 } & \multicolumn{5}{|c|}{ Fertilizers Applied. } & \multirow[b]{2}{*}{ 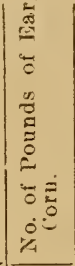 } & \multirow[b]{2}{*}{ 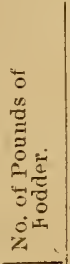 } & \multirow{2}{*}{\multicolumn{2}{|c|}{ 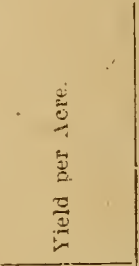 }} & \multirow{2}{*}{\multicolumn{2}{|c|}{ 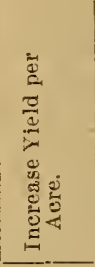 }} & \multirow[b]{2}{*}{ 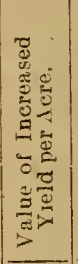 } & \multirow[b]{2}{*}{ 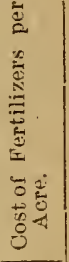 } & \multirow[b]{2}{*}{ 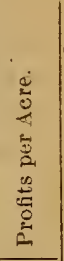 } & \multirow[b]{2}{*}{ 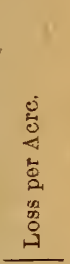 } \\
\hline & 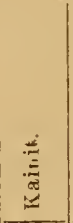 & 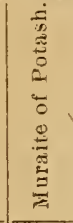 & 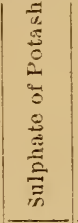 & 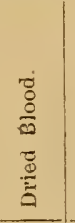 & 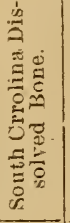 & & & & & & & & & & \\
\hline & Lbs. & Lbs. & Lbs. & Lbs. & Lus. & Los. & Lbs. & Bu. 1 & Lbs. & Bu. I & Lbs & Dols. & Dols. & Dols. & Dols. \\
\hline 17 & Noth & ing & & & & 305 & 262 & 69 & 50 & & & & & & \\
\hline 10 & 33.33 & & & & & 270 & 266 & 61 & 50 & -6 & $\rightarrow 0$ & -3.14 & 2.80 & & 5.94 \\
\hline 19 & 33.33 & & & 16. 66 & & 331 & 243 & 75 & 46 & 7 & 46 & 3.83 & 8.13 & & 4. 30 \\
\hline 20 & 33.33 & & & & 33.33 & $28 \div$ & 207 & 64 & 32 & -3 & 38 & $-1.7 \%$ & 6. 53 & & 8.30 \\
\hline$\because 1$ & 33. 33 & & & 16.66 & 33.33 & 292 & 200 & 66 & 52 & $-1 \mid$ & 18 & -0.63 & 11.86 & & 12.49 \\
\hline 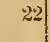 & Noth & ing & & & & 290 & 207 & 66. & 20 & & & & & & .. \\
\hline$\sim 0$ & & 9.33 & & & & 295 & 222 & 67 & $30^{\circ}$ & 0 & 40 & 0.28 & 2.98 & & 2.70 \\
\hline 24 & & 9.3 & & 16. 66 & & 307 & 260 & 70 & 12 & 3 & 22 & 1. 66 & 8. 31 & & 6.65 \\
\hline an & & 9.33 & & & 33.33 & 336 & 232 & 76 & 56 & 9 & 66 & $4.9 \pi$ & 6.71 & & 1.74 \\
\hline 26 & & 9.33 & & 16. 66 & $: 33.83$ & 308 & 272 & 70 & 28 & 3 & 38 & 1.77 & 12.04 & & 10.27 \\
\hline 27 & Noth & $\operatorname{ing}$ & & & & $: 995$ & 209 & 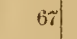 & 30 & & & & & & \\
\hline & & & 9. & & & 283 & $2 \pi 0$ & 64 & 48 & -6 & 60 & -3.43 & 3.74 & & 7.17 \\
\hline 29 & & & 9.00 & 16.66 & & 295 & 195 & 68 & 30 & -4 & 08 & -2.05 & 9.07 & & 11.12 \\
\hline 30 & & & 9.00 & & 33.33 & 302 & 246 & $69 ?$ & 2 & -2 & 36 & -1.25 & 7.47 & & 8.72 \\
\hline 31 & & & 9.00 & 16.66 & 33.33 & 315 & 262 & 72 & 0 & 0 & 32 & 0.23 & 12.80 & & 12.57 \\
\hline 32 & Noth & $\operatorname{ling}$ & & & & 331 & 280 & $75 !$ & - & & & & & & $\cdots$ \\
\hline
\end{tabular}


The land upon which the experiment was conducted in Putnam county, is Kanawha river bottom. The soil is illuvial in character and is a dark clay lotm. The experiments made thereon are of an unsatisfactory character. Mr. Biown states that the "fertilizers were applied June roth, when the corn was nearly knee high." This, we think, fully accounts for the unfavorable effects produced by the fortilizers, and sthows that to be effective and beneficial, the plant food should be applied so as to be available in the earliest stages of plant growth. From an inspection of this table, it will. be seen that one-haif of the fertilized plats produced a decreased yield, while none of the $m$ produced an increased yield sufficient to pay for the fertilizers applied. The ground upon which this experiment was conducted has be en abandoned and no more experiments will ve made upon it, (the location upon this farm having been changed) therefore, the table is oniy valuabluable as showing that it is very bad practice to apply commercial fertilizers to growing corn after the corn is "knee high."

The foregoing are the first in a series of expar ments which it is proposed to carry on at the out-etations and continue throngh several years. Alrhough there are many important facts shown in these tables, which woulu seem to indicat very strongly the kind and character of the plant food which should be supplied to the various soils 'treated, yet from one experiment alone, we will not attempt to draw any definite conclusion. 
$x$ 
